\title{
五大连池火山土壤细菌多样性及其群落结构
}

\author{
黄庆阳 ${ }^{1,2}$, 杨 帆 $^{1}$, 谢立红 ${ }^{1}$, 曹宏杰 ${ }^{1}$, 罗春雨 ${ }^{1}$, 王继丰 ${ }^{1}$, 焉志远 ${ }^{1}$, 倪红伟 ${ }^{2,3}, *$ \\ 1 黑龙江省科学院自然与生态研究所, 哈尔滨 150040 \\ 2 湿地与生态保育国家地方联合工程实验室，哈尔滨 150040 \\ 3 黑龙江省林业科学院, 哈尔滨 150081
}

摘要: 火山熔岩生境孕育了独特的土壤微生物群落。为了解火山生态系统土壤细菌群落多样性和群落结构及其关键影响因子, 选择五大连池新、老期火山为研究样点, 非火山为对照, 基于高通量测序方法, 分析不同采样点土壤细菌群落结构和多样性, 结 合土壤理化指标,进一步分析影响火山生态系统土壤细菌群落多样性的环境因子。结果表明: 细菌操作分类单元 (OTUs)、Ace 指数、Chao1 指数和 Simpson 指数变化趋势一致, 表现为非火山>新期火山>老期火山。三个样点土壤的共有 OUTs 数量为 713 个,各自特有的 OTUs 数量不尽相同。三个样点土壤中检测到共有细菌 16 个类群, 其中变形菌门、酸杆菌门、放线菌门和绿弯 菌门为优势菌群, 老期火山土壤中酸杆菌门、疮微菌门、Rokubacteria 相对丰度最大, 而 Patescibacteria 相对丰度最小。三个样点 的土壤细菌群落具有明显的空间关系, 相似性差异较大,但不符合随地理距离的增加而降低的模型。土壤理化性质测定结果标 明: 老期火山土壤 $\mathrm{pH}$ 、有机质、全氮、全磷、铵态氮和硝态氮显著高于新期火山和非火山, 新期火山土壤含水量和速效磷显著低 于老期火山和非火山。喷发时间和火成岩基质等特性会导致不同火山土壤理化性质的差异,进而影响土壤细菌多样性和群落 结构。Pearson 相关性分析表明: 土壤 $\mathrm{pH}$ 显著影响细菌的多样性指数。冗余分析( RDA) 结果表明: 土壤氮含量、 $\mathrm{pH}$ 和有机质是 影响火山森林生态系统土壤细菌群落结构的主要因子。

关键词:五大连池; 火山灰土; 细菌多样性;群落结构;土壤 $\mathrm{pH}$

\section{Diversity and community structure of soil bacteria in different volcanoes, Wudalianchi}

HUANG Qingyang ${ }^{1,2}$, YANG Fan ${ }^{1}$, XIE Lihong ${ }^{1}$, CAO Hongjie ${ }^{1}$, LUO Chunyu ${ }^{1}$, WANG Jifeng ${ }^{1}$, YAN Zhiyuan ${ }^{1}$, NI Hongwei ${ }^{2,3, *}$

1 Institute of Natural Resources and Ecology, Heilongjiang Academy of Sciences, Harbin 150040, China

2 National and Provincial Joint Engineering Laboratory of Wetlands and Ecological Conservation, Harbin 150040, China

3 Heilongjiang Academy of Forestry, Harbin 150081, China

\begin{abstract}
Volcanic lava habitats breed unique soil microbial communities. Soil bacterial diversity, community structure, and key factors influencing volcanic ecosystems were explored using soil microorganisms in new volcano soils and old volcano soils in Wudalianchi, Heilongjiang Provice. Non-volcano soils were used as the control. Using the Illumina high-throughput sequencing method, we analyzed soil bacterial community structure and diversity at three sampling sites. Combined with soil physical and chemical characteristics, environmental factors affecting the diversity of soil bacterial community in a volcanic ecosystem were analyzed. Results showed that the operational taxonomic units (OTUs) and the diversity index (the Ace index, the Chao 1 index, and the Simpson index) of bacteria presented the same trends and followed the order
\end{abstract}

基金项目: 国家自然科学基金(31770497); 黑龙江省科学院项目(YY2019ZR01,CXJQ2021ZR01,KY2021ZR03)

收稿日期: 2020-09-28; 采用日期: 2021- 08-05

* 通讯作者 Corresponding author.E-mail: nihongwei2000@ 163.com 
Non-volcano>new volcano $>$ old volcano. The number of OTUs unique to new volcano soils, old volcano soils and Nonvolcano soils were 852,820 , and 879 respectively, as well as the number of their common OTUs was 713 . The three plots soils contained same 16 kinds of bacterial groups, and Proteobacteria, Acidobacteria, Actinobacteria, and Chloroflexi were the most dominant bacteria groups. Acidobacteria, Verrucomicrobia, and Rokubacteria had the highest relative abundances, whereas Patescibacteria had the lowest in the old volcanic soils. In the three plots, the soil bacterial communities had obvious spatial relationships, and their similarity in community structure varies greatly, It did not conform to the model of beta diversity, which similarity in bacterial composition gradually decreased with increasing geographical distance. We think it could be related to the volcanic eruption characteristics or magma composition. The obtained soil physicochemical properties indicated that soil $\mathrm{pH}$, Soil organic matter ( SOM), total nitrogen ( TN), total phosphorus ( TP), ammonium nitrogen $(\mathrm{AN})$, and nitrate nitrogen $(\mathrm{NN})$ in old volcanic soils were significantly higher than those in the new volcanic soils and non-volcanic soils, while water content and available phosphorus in the new volcanic soils were significantly lower than those in the old volcanic soils and non-volcanic soils. Volcanic eruption is a form of violent large-scale disturbance, the volcanic characteristics of eruption time and igneous rock led to differences among volcanic soils at different stages, and further led to differences among soil bacterial diversity and community structure. Pearson correlation analysis showed that soil pH significantly affected the Simpson index, the Ace index and the Chao 1 index of soil bacteria. The redundancy analysis (RDA) showed that soil nitrogen, soil $\mathrm{pH}$, and SOM were the crucial factors affecting the bacterial community structure of the Wudalianchi volcanic ecosystem.

Key Words: Wudalianchi; volcanic ash soil; bacterial diversity; community structure; soil pH

微生物作为地球最早出现的生命形式,决定了地球演化的方向和进程,推动了土壤的发生和发育 ${ }^{[1]}$ 。土 壤细菌作为土壤微生物中种类和数量最多的类群, 参与了大部分土壤生态过程, 如地球化学循环、能量流动以 及信息传递等 ${ }^{[2-3]}$ 。土壤细菌对环境变化十分敏感, 其群落组成和多样性会对环境条件改变迅速响应, 是评 价土壤环境质量的重要指标 ${ }^{[4]}$ 。良好的土壤细菌结构和较高的细菌多样性能够提高细菌活性, 改善土壤理 化性质, 对土壤营养循环的贡献就可能越大 ${ }^{[4-5]}$ 。

火山喷发后生物地球化学循环和植被更新演替都发生了改变, 原生演替从裸岩重新开始 ${ }^{[6]}$,包括植被、 土壤和微生物等各种生态过程。火山土壤来源于火山熔岩和火山灰, 富含大量的微量元素和金属元素, 与世 界其他类型的土壤具有明显的差异特征, 可能导致不同的微生物活性 ${ }^{[7-8]}$ 。

火山土壤微生物的研究常见于 Biolog 微孔板法、磷脂脂肪酸法 (PLFA) 等传统方法, 较多集中在日本富士 火山 ${ }^{[7]}$ 、美国圣海伦火山 ${ }^{[9]}$ 和五大连池火山群 ${ }^{[10-11]}$ 等火山活跃区。Yoshitake ${ }^{[6]}$ 认为火山演替初期土壤微生 物量和微生物多样性较低, 并随着演替的进行逐渐增高, 与土壤氮、碳等养分有显著相关; $\mathrm{Xu}$ 等 ${ }^{[10]}$ 和曹宏 杰 ${ }^{[11]}$ 认为五大连池新、老期火山的土壤微生物量具有显著差异, 以上研究说明火山上壤微生物量受到土壤环 境和土壤养分的显著影响。近年来, 高通量测序技术广泛应用于微生物群落结构和多样性的研究 ${ }^{[12-13]}$, 研究 发现火山中的变形菌门、酸杆菌门和放线菌门等优势菌, 均与来自岩心的火成岩玄武岩有关, 说明土壤细菌群 落结构受到火成岩基质的影响 ${ }^{[6,14]}$ 。潘虹等认为五大连池不同火山矿泥中古菌和细菌群落结构具有显著差 异, 并且存在大量潜在新种 ${ }^{[15-16]}$ 。

五大连池火山群具备原生而完整的植被生态演替过程, 是研究火山生态系统中植物、土壤与微生物等诸 多科学问题难得的科研基地,但有关五大连池火山土壤细菌群落结构和多样性的研究未见报道。土壤细菌的 空间分布格局存在显著的生境依赖性特征, 受土壤性质、植被、气候等多种环境因素的综合影响,因此本研究 选取同一气候条件下, 新、老期火山相同植被类型 (山杨-白桦林) 的土壤为研究对象, 采用高通量测序的方法 测定分析土壤细菌群落结构和多样性, 结合土壤理化指标, 探讨五大连池火山土壤细菌群落多样性和群落结 构及其关键影响因子, 为火山生态系统植被和土壤发育规律提供理论依据。 


\section{1 材料与方法}

\section{1 研究区概况}

五大连池位于中国黑龙江省,跨越 300 年至 200 万年间,形成了不同时间和空间格局的 14 座火山,包括 2 座新期火山 (至今 300 年, 保存着熔岩地貌)、12 座老期火山 ( 17 万年一 200 万年), 是中国保存最为完好的内 陆火山遗迹 ${ }^{[17]}$ 。五大连池山口湖地质公园位于火山群的东南部, 处于孙吴断裂带上, 是由断裂形成的以花岗 岩为主的低山丘陵 ${ }^{[18]}$ 。五大连池地区属于温带大陆性季风气候, 年均气温 $-0.5^{\circ} \mathrm{C}$, 年平均降水量 $473 \mathrm{~mm}$, 年 无霜期 $121 \mathrm{~d}$, 地带性土壤类型为暗棕壤 ${ }^{[19]}$ 。五大连池植被属于温带阔叶混交林, 但兼有寒温带针叶林区域 和温带森林草原区域的部分属性, 主要优势植物有山杨 (Populus davidiana)、白华 (Betula platyphylla)、黑桦 (Betula dahurica)、蒙古栋( Quercus mongolica)、香杨 (Populus koreana) 和落叶松 (Larix gmelinii) 等。

\section{2 土壤样品采集与处理}

2019 年 7 月在五大连池新期火山 (NV)、老期火山 (OV) 和山口湖地质公园 (非火山喷发, Non-V) (表 1), 选择山杨一白桦林进行土壤样品采集, 火山熔岩台地土壤很薄, 部分仅有 $10 \mathrm{~cm}$ 左右, 因此以 $0-10 \mathrm{~cm}$ 土壤层 中作为取样对象 ${ }^{[21]}$ 。在每个样地内选取 5 个 $20 \mathrm{~m} \times 20 \mathrm{~m}$ 的样方, 移除表面调落物和腐殖质层, 梅花状 5 点法 采集 0-10 $\mathrm{cm}$ 厚度的土壤, 充分混合后过 $2 \mathrm{~mm}$ 尼龙篮并分成 3 份,一份 $-80^{\circ} \mathrm{C}$ 保存用于土壤细菌测定; 一份 土壤自然风干用于土壤总碳、总氮和总磷的测定,一份土壤 $4^{\circ} \mathrm{C}$ 保存用于土壤含水量、 $\mathrm{pH}$ 、铵态氮、硝态氮和速 效磷的测定,室内试验于 2019 年 8 月完成。

表 1 研究样地的基本情况

Table 1 General characteristic of the study areas

\begin{tabular}{|c|c|c|c|}
\hline $\begin{array}{l}\text { 火山 } \\
\text { Plots }\end{array}$ & $\begin{array}{l}\text { 老黑山 ( NV) } \\
\text { New volcano }\end{array}$ & $\begin{array}{l}\text { 东焦得布山 (OV) } \\
\text { Old volcano }\end{array}$ & $\begin{array}{l}\text { 山口湖公园 ( Non-V) } \\
\text { Non-volcano }\end{array}$ \\
\hline 地理位置 Location & $48^{\circ} 42^{\prime} 32^{\prime \prime} \mathrm{N}, 126^{\circ} 07^{\prime} 06^{\prime \prime} \mathrm{E}$ & $48^{\circ} 39^{\prime} 13^{\prime \prime} \mathrm{N}, 126^{\circ} 16^{\prime} 30^{\prime \prime} \mathrm{E}$ & $48^{\circ} 28^{\prime} 20^{\prime \prime} \mathrm{N}, 126^{\circ} 30^{\prime} 30^{\prime \prime} \mathrm{E}$ \\
\hline 喷发时间 Eruption time & 300 年前 & 170000 - 190 000 年前 & 未喷发 \\
\hline 土壤条件 Soil type & $\begin{array}{l}\text { 火山石质土、生草火山 } \\
\text { 灰土 }\end{array}$ & $\begin{array}{l}\text { 暗棕壤火山灰、黑土性火山 } \\
\text { 灰土 }{ }^{20]}\end{array}$ & 暗棕壤土 \\
\hline 海拔 Altitude/m & 328 & 375 & 306 \\
\hline 坡向 Slope & 台地 & 台地 & 台地 \\
\hline 植被类型 Vegetation & 山杨-白桦林 & 山杨-白桦林 & 山杨-白桦林 \\
\hline 林下优势植物 Dominant undergrowth & 岩败酱、万年蒿 & 四花薹草、蚊子草 & 毛榛、四花呿草 \\
\hline 郁闭度 Crown density/\% & $30-50$ & $60-80$ & $60-80$ \\
\hline 林龄 Foreat age/a & $45 \pm 8.2$ & $28 \pm 2.1$ & $43 \pm 2.4$ \\
\hline 树高 Height/m & $3-5.5$ & $7-11$ & $10-16$ \\
\hline 胸径 Diameter at breast height $\mathrm{DBH} / \mathrm{cm}$ & $2.6-6.8$ & $6.8-8.5$ & $12-13.5$ \\
\hline
\end{tabular}

\section{3 土壤理化性质测定}

土壤 $\mathrm{pH}$ 的测定采用电极电位法; 土壤含水量采用烘干法; 有机质 (Soil Organic Matter, SOM) 和全氮 (Total Nitrogen, TN) 采用 CN 元素分析仪测定; 铵态氮 (Ammonia Nitrogen, AN) 和硝态氮 (Nitrate Nitrogen, $\mathrm{NN}$ ) 采用流动分析仪测定; 全磷 (Total phosphorus, TP) 和有效磷 (Available Phosphorous, AP) 采用钼锑抗比色 法测定。

\section{4 土壤细菌 DNA 提取、处理及上机流程}

利用土壤试剂盒 (MoBio PowerSoil, USA) 提取土壤总 DNA, 细菌 16S rRNA 扩增引物采用特异引物 (515F/806R)，物种分类采用 silva128/16s_bacteria 的细菌数据库进行比对和鉴定。高通量测序委托上海美 吉生物医药科技有限公司完成, 生物信息学分析利用微生物多样性 V4.0 云平台完成。微生物多样性数据已 提交到美国国家生物技术信息中心 ( National Center for Biotechnology Information, NCBI) 数据库, 获得登记号 
PRJNA716727。

\section{5 数据统计分析}

细菌多样性采用 Shannon 指数、Simpson 指数、Chao 1 指数和 Ace 指数表征,利用 SPSS 19.0 进行单因素 方差分析 (One-way ANOVA), 采用最小显著差异法 (Least Significant Difference, LSD) 比较数据组间的差异。 采用非度量多维尺度分析 (Non-metric Multidimensional Scaling Analysis, NMDS) 和非参数检验(Analysis of similarities, Anosim) 研究样本间群落组成的相似性或差异性。用皮尔森相关系数 (Pearson) 评定不同因子间 的相关性。采用 R 语言进行去趋势对应分析 (Detrended Correspondence Analysis, DCA) , 根据梯度值确定冗 余分析( Redundancy Analysis，RDA)，用 ggplot 作图。

\section{2 结果与分析}

\section{1 土壤理化性质}

新、老期火山和非火山的土壤理化性质具有显著差异 (表 2),三个样地土壤 $\mathrm{pH}$ 均呈弱酸性,老期火山土壤 $\mathrm{pH}$ 最大,非火山的土壤 $\mathrm{pH}$ 最小; 三个样地中土壤有机质、全氮、全磷、铵态氮和硝态氮具有显著差异,变化趋势 相同,表现为老期火山>非火山>新期火山; 新期火山的土壤含水量和速效磷显著低于老期火山和非火山。

\section{表 2 新、老期火山和非火山的土壤理化性质}

Table 2 Soil physical and chemical characteristics in new volcano, old volcano and non-volcano

\begin{tabular}{lcccccccc}
\hline $\begin{array}{l}\text { 火山类型 } \\
\text { Samples }\end{array}$ & $\mathrm{pH}$ & $\begin{array}{c}\text { 含水量 } \\
\mathrm{WC} / \\
\%\end{array}$ & $\begin{array}{c}\text { 有机质 } \\
\mathrm{SOM} / \\
(\mathrm{g} / \mathrm{kg})\end{array}$ & $\begin{array}{c}\text { 全氮 } \\
\mathrm{TN} / \\
(\mathrm{g} / \mathrm{kg})\end{array}$ & $\begin{array}{c}\text { 全磷 } \\
\mathrm{TP} / \\
(\mathrm{g} / \mathrm{kg})\end{array}$ & $\begin{array}{c}\text { 速效磷 } \\
\mathrm{AP} / \\
(\mathrm{mg} / \mathrm{kg})\end{array}$ & $\begin{array}{c}\text { 铵态氮 } \\
\mathrm{AN} /\end{array}$ & $\begin{array}{c}\text { 硝态氮 } \\
\mathrm{NN} /\end{array}$ \\
$(\mathrm{mg} / \mathrm{kg})$ & $\begin{array}{c}(\mathrm{mg} / \mathrm{kg}) \\
\text { 新期火山 NV }\end{array}$ \\
老期火山 OV & $5.08 \pm 0.02 \mathrm{~b}$ & $8.50 \pm 0.21 \mathrm{~b}$ & $74.05 \pm 2.67 \mathrm{c}$ & $1.38 \pm 0.05 \mathrm{c}$ & $0.36 \pm 0.01 \mathrm{c}$ & $10.20 \pm 0.96 \mathrm{~b}$ & $4.17 \pm 0.09 \mathrm{c}$ & $6.45 \pm 0.22 \mathrm{c}$ \\
非火山 Non-V & $5.45 \pm 0.02 \mathrm{a}$ & $50.38 \pm 1.01 \mathrm{a}$ & $363.12 \pm 2.03 \mathrm{a}$ & $13.29 \pm 0.10 \mathrm{a}$ & $0.95 \pm 0.01 \mathrm{a}$ & $19.30 \pm 3.10 \mathrm{a}$ & $70.30 \pm 2.46 \mathrm{a}$ & $104.45 \pm 0.98 \mathrm{a}$ \\
\hline
\end{tabular}

表中数据为平均值士标准差, 同列不同小写字母表示处理间差异显著 $(P<0.05)$; WC: 土壤含水量 Soil water content; SOM : 有机质 Soil organic matter; TN : 全氮 Total nitrogen; TP: 全磷 Total phosphorus; AP: 速效磷 Available phosphorus; AN: 铵态氮 Ammonia nitrogen; NN: 硝态氮 Nitrate nitrogen

\section{2 土壤样品测序结果及取样深度验证}

土壤样品通过优化过滤低质量序列后得到有效序列总数为 430240 , 序列长度 410-440 bp。三个样地土 壤细菌的稀释性曲线均趋向平缓(图 1), 且土壤测序的 Coverage 指数均大于 0.994 (表 2), 表明样品取样合 理,已经能够反映供试土壤样品的微生物群落组成。

在 $97 \%$ 相似度下进行 OTUs 聚类, 三个样地土壤细菌共得到 941 个 OTUs ( 图 2), 共有 OTUs 总数为 713 个,约占全部 OTUs 的 $75.77 \%$ 。新、老期火山和非火山的土壤细菌 OTUs 总数分别为 $852 、 820$ 和 879 个,表现 为非火山>新期火山>老期火山。

\section{3 土壤细菌群落多样性}

不同采样点土壤细菌 Ace 指数、Chao1 指数和 Simpson 指数具有显著差异,变化趋势一致表现为非火山> 新期火山>老期火山,三个样地土壤细菌 Shannon 指数无显著差异 (表 3)。

\section{表 3 新、老期火山和非火山多样性指数}

Table 3 Diversity index analysis of new volcano, old volcano and non-volcano

\begin{tabular}{lcccc}
\hline $\begin{array}{l}\text { 火山类型 } \\
\text { Samples }\end{array}$ & $\begin{array}{l}\text { Coverage 指数 } \\
\text { Coverage index }\end{array}$ & $\begin{array}{c}\text { Ace 指数 } \\
\text { Ace index }\end{array}$ & $\begin{array}{c}\text { Chao 1 指数 } \\
\text { Chao 1 index }\end{array}$ & $\begin{array}{c}\text { Shannon 指数 } \\
\text { Shannon index }\end{array}$ \\
\hline 新期火山 NV & $0.9967 \pm 0.0002 \mathrm{a}$ & $815.26 \pm 2.04 \mathrm{ab}$ & $825.64 \pm 6.92 \mathrm{ab}$ & $5.46 \pm 0.01 \mathrm{a}$ \\
$\begin{array}{l}\text { 老期火山 OV } \\
\text { 非火山 Non-V }\end{array}$ & $0.9963 \pm 0.0001 \mathrm{a}$ & $779.46 \pm 2.17 \mathrm{~b}$ & $795.70 \pm 5.71 \mathrm{~b}$ & $5.50 \pm 0.02 \mathrm{a}$ \\
\hline
\end{tabular}




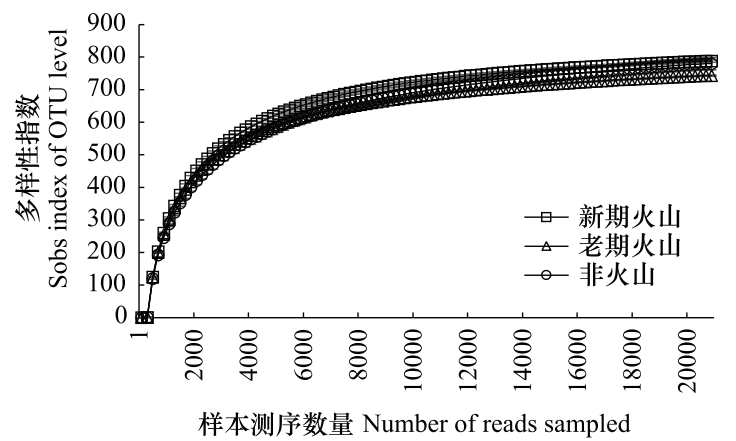

图 1 相似度为 0.97 条件下各土壤样品的稀释性曲线

Fig.1 Rarefation curves of each soil sample at similarity of 0.97 $\mathrm{NV}$ : 新期火山 New volcano; OV : 老期火山 Old volcano; Non-V : 非 火山 Non volcano

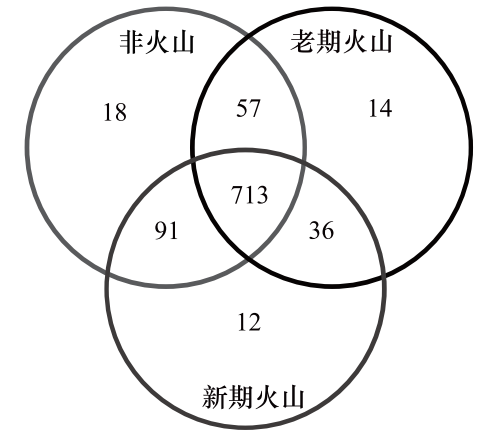

图 2 新、老期火山和非火山细菌群落的 OTUs 比较

Fig.2 OTUs comparison of bacteria in new volcano, old volcano and non-volcano

OTUs:操作分类单元 Operational taxonomic units

$\beta$ 多样性分析表明不同生境中的细菌群落相似性差异较大 (图 3)。其中, 新期火山和非火山的细菌群落 差异最小, 样品间差异指数仅为 0.43 ; 新期火山和老期火山的细菌群落样品相似性次之, 样品间差异指数为 0.56 ; 老期火山和非火山的细菌群落差异最大, 样品间差异指数为 0.59 。

\section{4 土壤细菌群落结构分析}

在门上水平, 新、老期火山和非火山土壤分别检测 出 $17 、 18$ 和 17 个细菌类群, 三个样地的土壤细菌群落 组成基本一致, 共有细菌 16 个类群, 其中相对丰度 $\geqslant$ $1 \%$ 的类群有 10 个 (图 4 ), 包括变形菌门 (Proteobacteria) $(41.64 \%, 32.64 \%, 43.35 \%)$, 放线菌门 (Actinobacteria) $(29.29 \%, 40.09 \%, 29.80 \%)$, 酸杆菌门 (Acidobacteria) $(13.67 \%, 7.84 \%, 11.43 \%)$, 绿弯菌门 (Chloroflexi) (6. 23\%, 9.69\%, 3. 84\%), 拟杆菌门 (Bacteroidetes) $(3.14 \%, 2.09 \%, 3.20 \%)$, Patescibacteria $(2.72 \%, 0.29 \%, 2.79 \%)$, 疮微菌门( Verrucomicrobia) $(0.58 \%, 3.29 \%, 1.32 \%)$, Rokubacteria $(0.10 \%, 2.41 \%$,

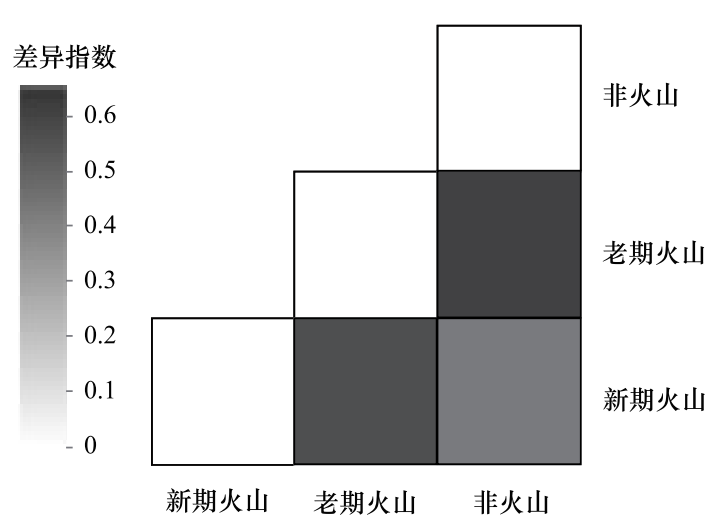

图 3 新、老期火山和非火山土壤细菌 beta 多样性分析

Fig.3 Analysis of beta diversity of soil bacteria in new volcano, old volcano and non-volcano

$0.10 \%)$, 芽单胞菌门 (Gemmatimonadetes) ( $1.07 \%$, $0.69 \%, 0.97 \%)$, 浮霉菌门 ( Planctomycetes) $(0.73 \%, 0.23 \%, 1.50 \%)$ 。其中变形菌门和酸杆菌门在三个样地土 壤中相对丰度均大于 $10.0 \%$, 显著高于其他细菌, 是细菌中的优势菌门。

三个样地土壤中酸杆菌门 $(P<0.05) 、$ Patescibacteria $(P<0.05)$ 、疮微菌门 $(P<0.01)$ 和 Rokubacteria $(P<$ 0.05 ) 具有显著差异或极显著差异, 其中老期火山土壤酸杆菌门、疮微菌门、Rokubacteria 具有最大值; 而老期 火山土壤 Patescibacteria 的相对丰度最小。

\section{5 土壤群落结构差异性分析}

利用非度量多维尺度法 (NMDS) 分析土壤细菌群落物种组成上的差异性, 结果显示胁强系数 Stress 为 0.025 , 可以准确反应样品组间的差异程度 (图 5 )。三个样地土壤细菌群落明显分开,形成不同的类群,空间 差异显著 $(R=0.684, P=0.001)$, 组间差异远大于组内差异。

\section{6 土壤细菌与土壤因子的关系}

土壤细菌 Ace 指数、Chao1 指数和 Simpson 指数与土壤 $\mathrm{pH}$ 呈显著负相关 $(P<0.05)$, 其他多样性指数与土 壤因子无显著相关性 $(P>0.05)$ (表 4$)$ 。 


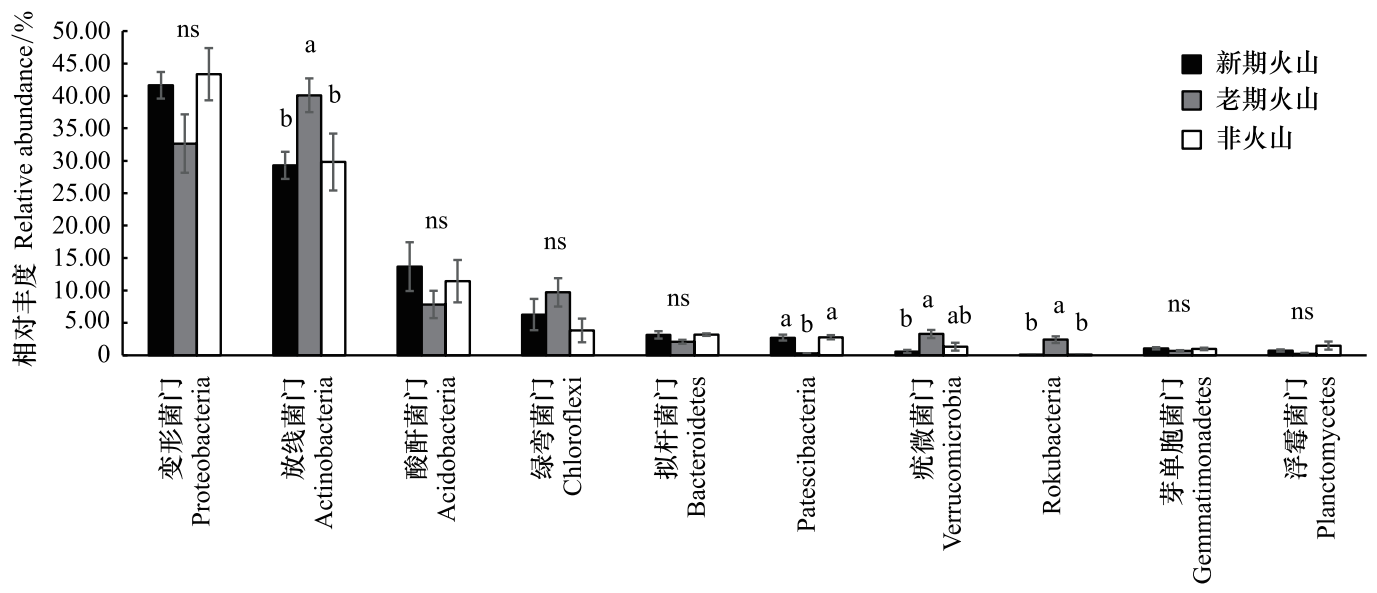

图 4 新、老期火山和非火山土壤门水平细菌相对丰度

Fig.4 Soil bacteria relative abundance of the phylum level in new volcano, old volcano and non-volcano

不同小写字母间表示差异显著 $(P<0.05)$; Proteobacteria : 变形菌门; Actinobacteria : 放线菌门; Acidobacteria：酸酤菌门; Chloroflexi: 绿弯菌 门; Bacteroidetes: 拟杆菌门; Verrucomicrobia：疫微菌门; Gemmatimonadetes：芽单胞菌门; Planctomycetes; 浮霉菌门; ns：无显著性 No significant
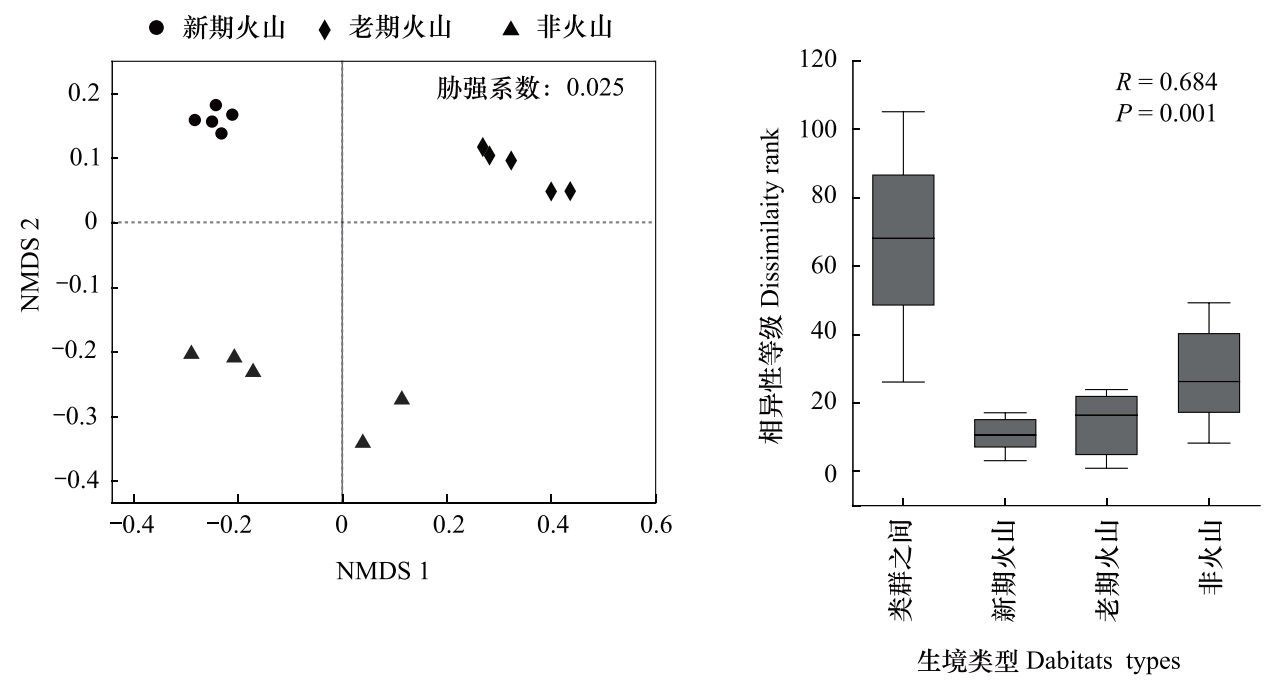

图 5 基于 OTUs 水平的 Bray-Curtis 的非度量多维尺度和相似性分析

Fig.5 Analysis of nonmetric multidimensional scaling and similarity at the OTUs level of bacterial communities

NMDS: 非度量多维尺度分析 Non-metric multidimensional scaling analysis; Between: 类群之间

表 4 细菌群落多样性与土壤理化性质的 Pearson 相关性分析

Table 4 Pearson correlation coefficients between soil bacteria $\alpha$-diversity indices and soil physicochemical properties

\begin{tabular}{|c|c|c|c|c|c|c|c|c|}
\hline $\begin{array}{l}\text { 多样性指数 } \\
\text { Diversity index }\end{array}$ & $\mathrm{pH}$ & $\begin{array}{c}\text { 含水量 } \\
\text { WC }\end{array}$ & $\begin{array}{c}\text { 有机质 } \\
\text { SOM }\end{array}$ & $\begin{array}{l}\text { 全氮 } \\
\text { TN }\end{array}$ & $\begin{array}{l}\text { 全磷 } \\
\mathrm{TP}\end{array}$ & $\begin{array}{c}\text { 铵态氮 } \\
\text { AN }\end{array}$ & $\begin{array}{c}\text { 硝态氮 } \\
\text { NN }\end{array}$ & $\begin{array}{c}\text { 速效磷 } \\
\text { AP }\end{array}$ \\
\hline Shannon 指数 Shannon index & 0.550 & -0.238 & 0.169 & 0.137 & -0.072 & 0.086 & 0.325 & -0.196 \\
\hline Simpson 指数 Simpson index & $-0.741^{*}$ & 0.070 & -0.425 & -0.387 & -0.141 & -0.340 & -0.584 & 0.071 \\
\hline Ace 指数 Ace index & $-0.701^{*}$ & -0.049 & -0.484 & -0.429 & -0.208 & -0.442 & -0.618 & 0.044 \\
\hline Chaol 指数 Chaol index & $-0.703 *$ & 0.081 & -0.387 & -0.326 & -0.089 & -0.333 & -0.549 & 0.172 \\
\hline
\end{tabular}

在门水平, 变形菌门平均相对丰度与 $\mathrm{pH}$ 和硝态氮呈显著负相关 $(P<0.05)$; 放线菌门与 $\mathrm{pH}$ 呈显著正相 
关 $(P<0.05)$, 与有机质、全氮、铵态氮和硝态氮呈极显著正相关 $(P<0.01)$; 绿弯菌门与 $\mathrm{pH}$ 呈显著正相关 $(P<$ $0.05)$; 拟杆菌门和 Patescibacteria 与 $\mathrm{pH}$ 、有机质、全氮、铵态氮呈显著负相关 $(P<0.05)$, 与硝态氮呈极显著负 相关 $(P<0.01)$; Rokubacteria 与 $\mathrm{pH}$ 、有机质、全氮、铵态氮和硝态氮呈极显著正相关 $(P<0.01)$; 芽单胞菌门与 有机质、全氮、铵态氮和硝态氮呈极显著负相关 $(P<0.05)$, 可见, 土壤 $\mathrm{pH}$ 、有机质、全氮、铵态氮和硝态氮对门 水平细菌群落组成的影响程度较大 (表 5)。

表 5 优势细菌类群与土壤因子相关性分析

Table 5 Correlation coefficients between dominant bacteria groups and edaphic factors

\begin{tabular}{|c|c|c|c|c|c|c|c|c|}
\hline $\begin{array}{l}\text { 细菌类群 } \\
\text { Bacteria group }\end{array}$ & $\mathrm{pH}$ & $\begin{array}{c}\text { 含水量 } \\
\mathrm{WC}\end{array}$ & $\begin{array}{c}\text { 有机质 } \\
\text { SOM }\end{array}$ & $\begin{array}{l}\text { 全氮 } \\
\text { TN }\end{array}$ & $\begin{array}{l}\text { 全磷 } \\
\text { TP }\end{array}$ & $\begin{array}{c}\text { 铵态氮 } \\
\text { AN }\end{array}$ & $\begin{array}{l}\text { 硝态氮 } \\
\text { NN }\end{array}$ & $\begin{array}{c}\text { 速效磷 } \\
\text { AP }\end{array}$ \\
\hline 变形菌门 Proteobacteria & $-0.707^{*}$ & -0.229 & -0.652 & -0.627 & -0.440 & -0.594 & $-0.741 *$ & -0.259 \\
\hline 放线菌门 Actinobacteria & $0.738 *$ & 0.466 & $0.835^{* * *}$ & $0.802^{* * *}$ & 0.628 & $0.804^{* * *}$ & $0.884^{* *}$ & 0.319 \\
\hline 酸酩菌门 Acidobacteria & -0.316 & -0.455 & -0.555 & -0.548 & -0.497 & -0.568 & -0.529 & -0.346 \\
\hline 绿弯菌门 Chloroflexi & $0.735^{*}$ & 0.031 & 0.515 & 0.477 & 0.252 & 0.464 & 0.656 & 0.017 \\
\hline 拟杆菌门 Bacteroidetes & $-0.736^{*}$ & -0.365 & $-0.773 *$ & $-0.737^{*}$ & -0.549 & $-0.739^{*}$ & $-0.840^{* *}$ & -0.322 \\
\hline Patescibacteria & $-0.750^{*}$ & -0.387 & $-0.784^{*}$ & -0.751 * & -0.573 & $-0.746^{*}$ & $-0.850^{* *}$ & -0.266 \\
\hline 病微菌门 Verrucomicrobia & 0.418 & 0.388 & 0.594 & 0.599 & 0.515 & 0.568 & 0.597 & 0.562 \\
\hline Rokubacteria & $0.842^{* *}$ & 0.458 & $0.905^{* * *}$ & $0.873^{* * *}$ & 0.664 & $0.850^{* *}$ & $0.975^{* *}$ & 0.413 \\
\hline 芽单胞菌门 Gemmatimonadetes & -0.547 & -0.487 & $-0.761^{*}$ & $-0.757^{*}$ & -0.651 & $-0.732 *$ & $-0.765 *$ & -0.482 \\
\hline 浮霉菌门 Planctomycetes & -0.644 & 0.071 & -0.344 & -0.288 & -0.069 & -0.304 & -0.494 & 0.180 \\
\hline
\end{tabular}

趋势对应分析 (DCA) 第一排序轴的梯度长度小于 3 ,采用穴余分析 (RDA) 解释细菌群组成与土壤因子的 关系,结果显示: 前两轴累计方差解释比 $88.60 \%$,能较 为完整地反映排序信息 (图 6)。土壤因子与第一排序 轴相关性按相关系数 (绝对值) 的大小: 硝态氮 $>\mathrm{pH}$ 值 $>$ 有机质 $>$ 全氮 $>$ 铵态氮 $>$ 全磷 $>$ 含水量 $>$ 速效磷。

\section{3 讨论}

本研究中,新期火山土壤中有机质、全氮、硝态氮、 铵态氮、全磷和速效磷显著低于老期火山, 表明火山喷 发后随着演替的正向进行, 土壤养分含量逐渐升高, 这 可能是因为随着年代的逐渐增加, 土壤发育程度加深, 有机质不断积累 ${ }^{[22]}$ 。另外新期火山的熔岩表面干燥、 平坦、裸露度较高不易留存调落物, 调落物稀少导致输 人土壤中有机营养和无机含量缺乏 ${ }^{[6]}$ 。非火山-山口湖 地质公园的土壤的有机质、全氮、全磷、硝态氮和铵态氮 与新、老期火山土壤具有显著差异, 这可能是因为养分 主要与成土母质、风化程度、淋溶强度有关 ${ }^{[22]}$, 五大连 池火山群的喷发物质均来自第四纪火山活动形成的岩 浆源 ${ }^{[23]}$, 具有玄武岩性质, 而非火山-山口湖地质公园

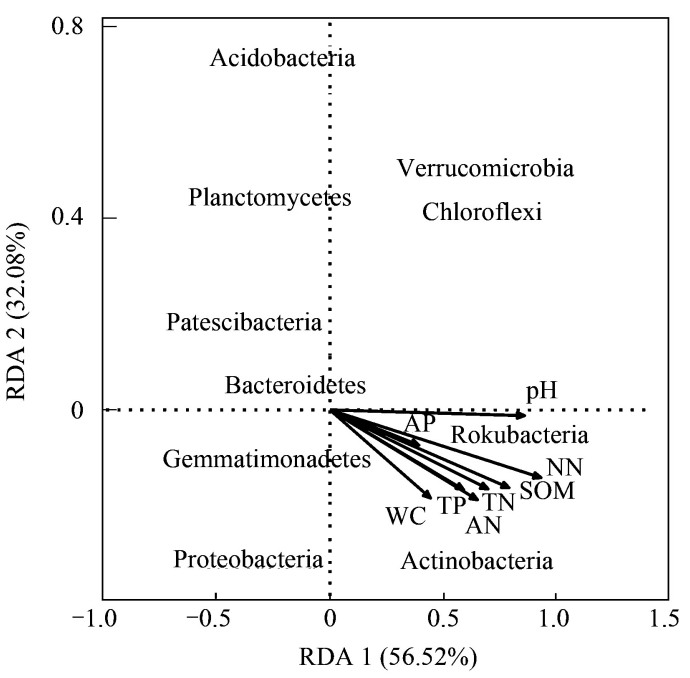

图 6 门水平细菌群落组成与土壤环境因子的典型相关分析

Fig.6 Canonical correlation analysis of soil bacteria community compositions of the phylum level and soil factor

RDA: 几余分析 Redundancy analysis; WC: 土壤含水量 Soil water content; SOM : 有机质 Soil organic matter; TN : 全氮 Total nitrogen; TP: 全磷 Total phosphorus; AP : 速效磷 Available phosphorus; AN : 铵态氮 Ammonia nitrogen; NN : 硝态氮 Nitrate nitrogen 的土壤由花岗岩风化而成。Wang ${ }^{[24]}$ 也认为在植被与土壤协同演化的过程中,不同森林生态系统中的土壤理 化性质呈现一定的差异。因此,五大连池火山土壤理化性质受到调落物数量和火山喷发时间、火山成土母质 等火山特性的共同影响。 
$\beta$ 多样性可以度量动、植物和微生物等群落物种组成随环境梯度的变化程度 ${ }^{[25]}$ 。Bray-Curtis 距离分析显 示新期火山、老期火山与非火山细菌群落相似性差异较大,但结果并不符合细菌群落 $\beta$ 多样性随地理距离的 增加而降低的模型 ${ }^{[26]}$, 这可能与火山喷发出的特性或者岩浆成分有关。毛翔 ${ }^{[27]}$ 认为五大连池火山喷发带中 的一条 $\mathrm{E}-\mathrm{W}$ 方向的断裂带,将老期火山东焦得布山、卧虎山和药泉山划分为五大连池南侧的构造单元, 导致 通过该断裂带喷出的深层岩浆或变质物质与该地区所属的松辽盆地并不十分一致 ${ }^{[28]}$, 因此有可能导致东焦 得布山与非火山和新期火山的土壤微生物差异较大。

在不同的森林生态系统中, 土壤主要的微生物群落组成基本上是近似的 ${ }^{[5,29]}$, 本研究土壤中变形菌门、酸 杆菌门、放线菌门和拟杆菌门的相对丰度较高, 是五大连池火山土壤中的优势菌类, 与其他森林生态系统差别 不大。而五大连池火山爆发这种剧烈的扰动, 改变了沉积层火山物质组分, 导致微生物代谢类型及功能的多 样性,进而影响细菌的群落结构 ${ }^{[7]}$ 。变形菌门已经被证实与来自岩心的玄武岩有关 ${ }^{[30-31]}$, 具有增强玄武岩的 风化作用和能够在贫痊环境生长的能力 ${ }^{[32]}$, 并被视为在玄武岩环境中作为碳源和氮源关键的细菌类群, 可以 浸出磷和硫元素; 老期火山土壤中放线菌门和疮微菌门的相对丰度显著高于新期火山和非火山土壤, 这可能 与玄武岩性质有关系, 疮微菌门也被证实与北极环境中玄武岩风化作用有关 ${ }^{[33]}$ 。

地上植被、土壤环境因子以及土壤理化性质与土壤微生物之间存在着复杂的关系网 ${ }^{[34]}$ 。本研究中土壤 $\mathrm{pH}$ 与 3 种细菌多样性和 6 种细菌类群具有显著或极显著的相关性, 这说明土壤 $\mathrm{pH}$ 是土壤细菌多样性和群落 结构的重要控制因子, Zhu 等 ${ }^{[35]}$ 和 Shen 等 ${ }^{[36]}$ 在干旱或者潮湿等多种生态环境中,也得到了相同的结论。土 壤有机质、全氮、硝态氮、铵态氮等与放线菌门、拟杆菌门和 Patescibacteria 等细菌类群也有显著的相关性,说 明森林演替过程中土壤有机质和氮素变化与细菌群落组成变化密切相关 ${ }^{[4]}$, 这是由于地上调落物成分、质量 影响土壤表层有机质和氮含量的变化, 导致土壤微生物群落结构存在差异 ${ }^{[37]}$ 。曹永昌 ${ }^{[38]}$ 也认为在土壤发育 初期积累的碳显著高于氮,氮素成为土壤中微生物生长的限制因素。

\section{4 结论}

五大连池火山土壤细菌 Ace 指数、Chao1 指数和 Simpson 指数均显著低于非火山土壤; 新、老期火山和非 火山土壤细菌包括变形菌门、酸杆菌门、放线菌门和绿弯菌门等优势菌门,但三个样地土壤细菌群落空间差异 显著,其中酸杆菌门、Patescibacteria、疮微菌门和 Rokubacteria 是差异菌群。火山喷发是一种剧烈的大规模扰 动形式, 喷发时间和火成岩基质等特性会导致不同火山土壤理化性质的差异,进而影响土壤细菌多样性和群 落结构。我们认为土壤 $\mathrm{pH}$ 、有机质和氮含量是驱动五大连池火山森林生态系统土壤细菌多样性和群落结构 变化重要的影响因子。

\section{参考文献 (References) :}

［1］朱永官, 沈仁芳, 贺纪正, 王艳芬, 韩兴国, 贾仲君. 中国土壤微生物组: 进展与展望. 中国科学院院刊, 2017, 32(6)：554-565.

[ 2 ] Van der Heijden M G A, Bardgett R D, Van Straalen N M. The unseen majority: soil microbes as drivers of plant diversity and productivity in terrestrial ecosystems. Ecology Letters, 2008, 11: 296-310.

[ 3 ] Leff J W, Jones S E, Prober S M, Barberán A, Borer E T, Firn J L, Harpole W S, Hobbie S E, Hofmockel K S, Knops J M H, McCulley R L, La Pierre K, Risch A C, Seabloom E W, Schütz M, Steenbock C, Stevens C J, Fierer N. Consistent responses of soil microbial communities to elevated nutrient inputs in grasslands across the globe. Proceedings of the National Academy of Sciences of the United States of America, 2015,112 (35) : 10967-10972.

[ 4 ] 张晓, 刘世荣, 黄永涛, 傅声雷. 辽东栋林演替过程中的土壤细菌群落结构和多样性变化. 林业科学, 2019, 55(10): 193- 202.

[ 5 ] 刘君, 王宁, 崔岱宗, 卢否, 赵敏. 小兴安岭大亮子河国家森林公园不同生境下土壤细菌多样性和群落结构. 生物多样性, 2019, 27(8): 911-918.

[ 6 ] 周志强, 徐丽娇, 张玉红, 夏春梅, 李洪光, 刘粀, 马克平. 黑龙江五大连池的生态价值分析. 生物多样性, 2011, 19(1): 63-70.

[ 7 ] Yoshitake S, Fujiyoshi M, Watanabe K, Masuzawa T, Nakatsubo T, Koizumi H. Successional changes in the soil microbial community along a vegetation development sequence in a subalpine volcanic desert on Mount Fuji, Japan. Plant and Soil, 2013, 364(1/2) : 261-272.

[ 8 ] Valle S R, Dörner J, Zúñiga F, Dec D. Seasonal dynamics of the physical quality of volcanic ash soils under different land uses in southern Chile. Soil and Tillage Research, 2018, 182: 25-34. 
[ 9 ] Gomez-Alvarez V, King G M, Nüsslein K. Comparative bacterial in recent Hawaiian volcanic deposits of different ages. FEMS Microbiology Ecology, 2007, 60(1): 60-73.

[10] Xu S Q, Zhang J F, Luo S S, Zhou X, Shi S H, Tian C J. Similar soil microbial community structure across different environments after long-term succession: evidence from volcanoes of different ages. Journal of Basic Microbiology, 2018, 58( 8) : 704-711.

[11] 曹宏杰, 王立民, 徐明怡, 黄庆阳, 罗春雨, 谢立红, 倪红伟. 五大连池新期火山熔岩台地不同植被类型土壤微生物量及酶活性变化特 征. 中南林业科技大学学报, 2019, 39(11): 88-97.

[12] Kelly L C, Cockell C S, Piceno Y M, Piceno Y M, Andersen G L, Thorsteinsson T, Marteinsson V. Bacterial diversity of weathered terrestrial icelandic volcanic glasses. Microbial Ecology, 2010, 60(4): 740-752.

[13] Yan X T, Yan B Y, Ren Q M, Dou J J, Wang W W, Zhang J J, Zhou J W, Long R J, Ding L M, Han J, Li Z. P, Qiu Q. Effect of slow-release urea on the composition of ruminal bacteria and fungi communities in yak. Animal Feed Science and Technology, 2018,244 : 18-27.

[14] Byloos B, Monsieurs P, Mysara M, Leys N, Boon N, Van Houdt R. Characterization of the bacterial communities on recent Icelandic volcanic deposits of different ages. BMC Microbiology, 2018, 18(1): 122.

[15] 潘虹, 谢振华, 王希英, 曾颖, 方振兴, 吴婧. 五大连池不同火山喷发沉积物的细菌群落多样性研究. 微生物学报, 2020, 60 ( 5) : 939-950.

[16] 潘虹, 王希英, 方振兴, 吴婧. 五大连池火山喷发沉积物古菌多样性及系统发育分析. 应用与环境生物学报, 2018, 24(5) : 1000-1008.

[17] 孙化江, 钟帮权. 五大连池火山地貌景观及其开发保护. 国土与自然资源研究, 2004, (3): 72-74.

[18] 张宏伟. 半湿润区和半干旱区湖泊沉积狍粉特征对比及其环境意义一一黑龙江省二龙山水库和内蒙古夏日布日都淖尔 [D]. 北京: 中国 地质大学(北京), 2012 .

[19] 谢立红, 黄庆阳, 曹宏杰, 倪红伟. 五大连池新期火山熔岩台地维管束植物物种多样性. 西北植物学报, 2017, 37(4) : 790-796.

[20] 张树民, 陈黎明, 邢润贵, 金凯忠. 五大连池火山区土壤和植被分布与特征. 国土与自然资源研究, 2005, (1): 86-88.

[21] 黄庆阳, 曹宏杰, 王立民, 谢立红, 倪红伟. 五大连池火山熔岩台地植物多样性与土壤养分的关系. 浙江农林大学学报, 2019, 36( 1): 80-87.

[22] 张星星, 杨柳明, 陈忠, 李一清, 林燕语, 郑宪志, 楚海燕, 杨玉盛. 中亚热带不同母质和森林类型土壤生态酶化学计量特征. 生态学报, $2018,38(16)$ : 5828-5836.

[23] 福英, 白学良, 张乐, 毕庚辰, 冯超, 寇瑾, 萨如拉. 五大连池火山熔岩地貌苔藓植物对土壤养分积累的作用. 生态学报, 2015, 35(10): 3288-3297.

[24] Wang Y Y, Guo D F. Response of soil fungi community structure to salt vegetation succession in the Yellow River Delta. Current Microbiology, 2016, 73(4): 595-601.

[25] 乔沙沙, 周永娜, 刘晋仙, 景炬辉, 贾彤, 李軞, 杨欣, 柴宝峰. 关帝山针叶林土壤细菌群落结构特征. 林业科学, 2017, 53(2): 89-99.

[26] 卢品, 金毅, 陈建华, 李铭红, 于明坚. 地理距离和地形差异对两个大型森林动态样地 $\beta$ 多样性的影响. 生物多样性, 2013, 21 ( 5): 554-563.

[27] 毛翔, 李江海, 高危言, 张天然. 黑龙江五大连池火山群火山分布与断裂关系新认识. 高校地质学报, 2010, 16(2): 226-235.

[28] Wang Y and Chen H. Tectonic controls on the Pleistocene-Holocene Wudalianchi volcanic field ( northeastern China). Journal of Asian Earth Sciences, 2005, 24(4): 419-431.

[29] Lin Y T, Huang Y J, Tang S L, Whitman W B, Coleman D C, Chiu C Y. Bacterial community diversity in undisturbed perhumid montane forest soils in Taiwan. Microbial Ecology, 2010, 59(2) : 369-378.

[30] Olsson-Francis K, Boardman C P, Pearson V K, Schofield P F, Oliver A, Summers S. A culture-independent and culture-dependent study of the bacterial community from the bedrock soil interface. Advances in Microbiology, 2015, 5(13) : 842-857.

[31] Cockell C S, Kelly L C, Marteinsson V. Actinobacteria - an ancient phylum active in volcanic rock weathering. Geomicrobiology Journal, 2013, 30 (8) : 706-720.

[32] Summers S, Whiteley A S, Kelly L C, Cockell C S. Land coverage influences the bacterial community composition in the critical zone of a subArctic basaltic environment. FEMS Microbiology Ecology, 2013, 86(3): 381-393.

[33] Bergen B, Herlemann D P R, Labrenz M, Jürgens K. Distribution of the verrucomicrobial clade Spartobacteria along a salinity gradient in the Baltic Sea. Environmental Microbiology Reports, 2014, 6(6): 625-630.

[34] 杨立宾, 隋心, 崔福星, 朱道光, 宋翰林, 倪红伟. 汤旺河国家公园不同演替阶段森林土壤细菌多样性变化规律. 环境科学研究, 2019, $32(3)$ : 458-464.

[35] Zhu S S, Vivanco J M, Manter D K. Nitrogen fertilizer rate affects root exudation, the rhizosphere microbiome and nitrogen-use-efficiency of maize. Applied Soil Ecology, 2016, 107: 324-333.

[36] Shen C C, Xiong J B, Zhang H Y, Feng Y Z, Lin X G, Li X Y, Liang W J, Chu H Y. Soil pH drives the spatial distribution of bacterial communities along elevation on Changbai Mountain. Soil Biology and Biochemistry, 2013, 57: 204-211.

[37] Lan G Y, Li Y W, Wu Z X, Xie G S. Impact of tropical forest conversion on soil bacterial diversity in tropical region of China. European Journal of Soil Biology, 2017, 83: 91-97.

[38] 曹永昌, 杨瑞, 刘帅, 王紫泉, 和文祥, 耿增超. 秦岭典型林分夏秋两季根际与非根际土壤微生物群落结构. 生态学报, 2017, 37( 5) : $1667-1676$. 